\title{
Eicosanoids and Respiratory Viral Infection: Coordinators of Inflammation and Potential Therapeutic Targets
}

\author{
Mary K. McCarthy ${ }^{1}$ and Jason B. Weinberg1,2 \\ ${ }^{1}$ Department of Microbiology and Immunology, University of Michigan, Ann Arbor, MI 48109, USA \\ ${ }^{2}$ Department of Pediatrics and Communicable Diseases, University of Michigan, Ann Arbor, MI 48109, USA
}

Correspondence should be addressed to Jason B. Weinberg, jbwein@umich.edu

Received 10 November 2011; Accepted 12 March 2012

Academic Editor: Lúcia Helena Faccioli

Copyright (C) 2012 M. K. McCarthy and J. B. Weinberg. This is an open access article distributed under the Creative Commons Attribution License, which permits unrestricted use, distribution, and reproduction in any medium, provided the original work is properly cited.

\begin{abstract}
Viruses are frequent causes of respiratory infection, and viral respiratory infections are significant causes of hospitalization, morbidity, and sometimes mortality in a variety of patient populations. Lung inflammation induced by infection with common respiratory pathogens such as influenza and respiratory syncytial virus is accompanied by increased lung production of prostaglandins and leukotrienes, lipid mediators with a wide range of effects on host immune function. Deficiency or pharmacologic inhibition of prostaglandin and leukotriene production often results in a dampened inflammatory response to acute infection with a respiratory virus. These mediators may, therefore, serve as appealing therapeutic targets for disease caused by respiratory viral infection.
\end{abstract}

\section{Respiratory Viruses}

Viruses are the most frequent cause of respiratory infection in humans. It has been estimated that viruses cause up to $90 \%$ of lower respiratory infection (LRI) hospitalizations in children less than 5 years of age and up to $40 \%$ of hospitalizations in children age 5-18 years [1]. Among the most common causes of viral respiratory infection in children and adults are respiratory syncytial virus (RSV), influenza, rhinovirus (RV), adenovirus, parainfluenza virus (PIV), and human metapneumovirus (hMPV) [2]. Viral respiratory infection also causes substantial disease burden in the elderly and immunocompromised populations $[3,4]$.

The host immune system faces the task of effectively clearing a virus while limiting local tissue damage and inflammation. The immune response to viruses can be protective, aiding with clearance of virus from the lungs and resolution of disease caused by viral replication. Disease associated with respiratory viruses can also be caused by immune-mediated pathology. Virus-induced inflammation can be detrimental to the host, causing symptoms during acute infection and leading to damage that contributes to long-term residual lung disease. Eicosanoids are potent lipid mediators that play a role in many biological processes, including inflammation and immune function. Two classes of eicosanoids, the prostaglandins (PGs) and leukotrienes (LTs), have been increasingly studied in the context of respiratory viral infection. Because of these effects, eicosanoids are likely to make significant contributions to the pathogenesis of respiratory virus infection.

\section{Eicosanoid Synthesis}

2.1. Prostaglandins. PGs are generated when phospholipase $\mathrm{A}_{2}\left(\mathrm{PLA}_{2}\right)$ releases arachidonic acid (AA) from membrane glycerophospholipids (Figure 1). Released AA is oxidized to the intermediate prostaglandin $\mathrm{H}_{2}\left(\mathrm{PGH}_{2}\right)$ by cyclooxygenase (COX). COX exists in three isoforms. COX-1 is generally constitutively expressed, while COX-2 expression is rapidly induced by growth factors and cytokines [5]. COX3 is a recently discovered isoform whose biological role, if any, remains poorly understood $[6,7]$. Once formed, $\mathrm{PGH}_{2}$ can be converted by specific synthases to thromboxane $A_{2}$ $\left(\mathrm{TXA}_{2}\right), \mathrm{PGD}_{2}, \mathrm{PGE}_{2}, \mathrm{PGF}_{2}$, and $\mathrm{PGI}_{2}$. As described below, $\mathrm{PGE}_{2}$ has multiple effects on host immune function. $\mathrm{PGE}_{2}$ is transported from the cell by multidrug resistance protein 


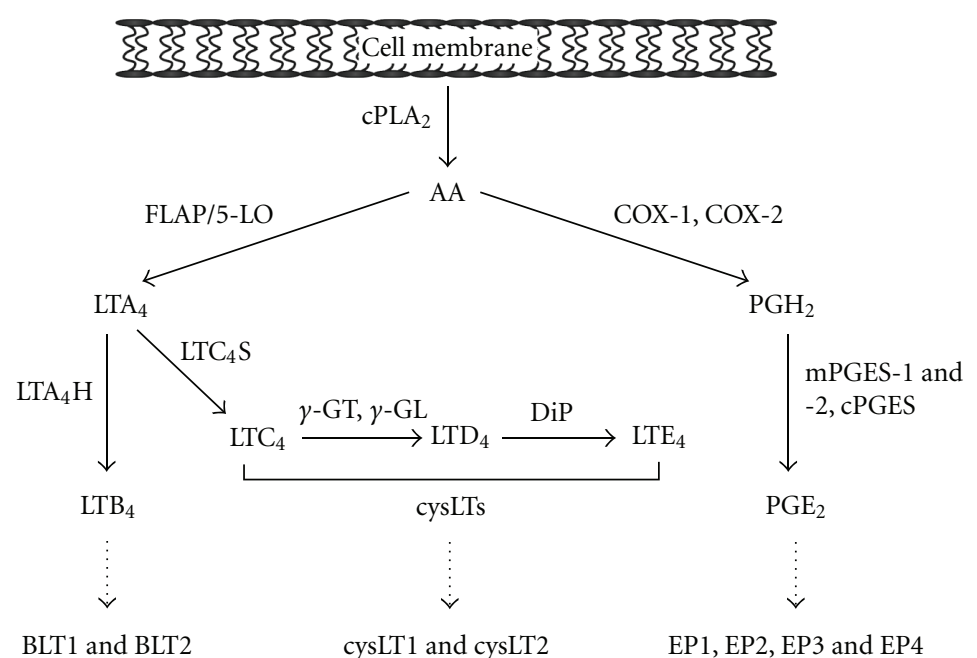

FIgure 1: Synthesis of $\mathrm{PGE}_{2}$ and the leukotrienes. $\mathrm{CPLA}_{2}$ - cytosolic phospholipase $\mathrm{A}_{2}$, AA—arachidonic acid, FLAP-5-lipoxygenase activating protein, 5-LO-5-lipoxygenase, $\mathrm{LTA}_{4}$-leukotriene $\mathrm{A}_{4}, \mathrm{LTA}_{4} \mathrm{H}$-leukotriene $\mathrm{A}_{4}$ hydrolase, $\mathrm{LTB}_{4}$ - leukotriene $\mathrm{B}_{4}$, BLT1 and BLT2-B leukotriene receptor 1 and 2, $\mathrm{LTC}_{4} \mathrm{~S}$-leukotriene $\mathrm{C}_{4}$ synthase, $\mathrm{LTC}_{4}$-leukotriene $\mathrm{C}_{4}, \gamma$-GT- $\gamma$-glutamyl transpeptidase, $\gamma$-GL$\gamma$-glutamyl leukotrienease, $\mathrm{LTD}_{4}$-leukotriene $\mathrm{D}_{4}$, DiP-dipeptidase, LTE $\mathrm{L}_{4}$-leukotriene $\mathrm{E}_{4}$, cysLTs-cysteinyl leukotrienes, cysLT1 and

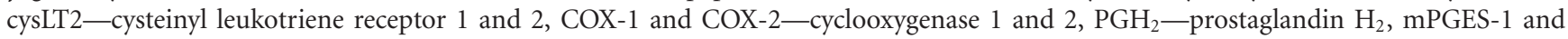
-2-microsomal prostaglandin E synthase-1 and -2, $\mathrm{PGE}_{2}$ - prostaglandin $\mathrm{E}_{2}$, EP1-4-E prostanoid receptors 1-4.

(MRP) 4 and possibly by other unknown transporters [8]. The effects of $\mathrm{PGE}_{2}$ are mediated by its signaling through four distinct $G$ protein-coupled $E$ prostanoid (EP) receptors, EP1-4. The EP1 receptor is coupled to an unidentified G protein and mediates $\mathrm{PGE}_{2}$-induced increases in intracellular $\mathrm{Ca}^{2+}$ [9]. The EP2 and EP4 receptors mediate increases in cyclic AMP (cAMP) concentration by coupling to $\mathrm{G} \alpha_{s}$. Four isoforms of the EP3 receptor are coupled to different $G$ proteins, although the major EP3 receptor signaling pathway involves adenylate cyclase inhibition via $\mathrm{G} \alpha_{i}$ coupling with subsequent decreases in intracellular cAMP [10]. The EP2 and EP4 receptors are expressed in almost all mouse tissues, while expression of EP1 is restricted to several organs, including the lung. EP2 expression is the least abundant of the EP receptors, however, several stimuli induce expression of EP2 [10].

2.2. Leukotrienes. LTs are also generated by liberation of AA from cell membranes (Figure 1). This is modified by a series of enzymes beginning with 5-lipoxygenase (5LO), which acts in concert with 5-LO-activating protein (FLAP) to form leukotriene $\mathrm{A}_{4}\left(\mathrm{LTA}_{4}\right)$ [11]. LTA 4 can then be metabolized by $\mathrm{LTA}_{4}$ hydrolase to form leukotriene $\mathrm{B}_{4}$ $\left(\mathrm{LTB}_{4}\right)$. Alternatively, $\mathrm{LTA}_{4}$ can be conjugated to reduced glutathione by leukotriene $\mathrm{C}_{4}\left(\mathrm{LTC}_{4}\right)$ synthase to form $\mathrm{LTC}_{4}$. $\mathrm{LTC}_{4}$ is exported from the cell by specific transporters [12] and can be acted on by extracellular peptidases to form LTD $_{4}$ or $\mathrm{LTE}_{4}$. Leukotrienes $\mathrm{C}_{4}, \mathrm{D}_{4}$, or $\mathrm{E}_{4}$ are collectively known as the cysteinyl leukotrienes (cysLTs).

Expression of 5-LO is tightly regulated and is primarily restricted to cells of the myeloid lineage, such as monocytes/macrophages, mast cells, eosinophils, and neutrophils. Although LT synthesis was once thought to be restricted to leukocytes, it has subsequently been shown that human bronchial epithelial cells and fibroblasts are capable of producing both cysLTs and $\mathrm{LTB}_{4}[13,14]$. In addition, the intermediate $\mathrm{LTA}_{4}$ can be transferred from an activated donor cell to a recipient cell. $\mathrm{LTA}_{4}$ can then be metabolized to either $\mathrm{LTB}_{4}$ or $\mathrm{LTC}_{4}$ by $\mathrm{LTA}_{4}$ hydrolase or $\mathrm{LTC}_{4}$ synthase, respectively, in a process termed "transcellular biosynthesis" [15]. These enzymes are expressed in most tissues. In this way, other cell types, such as epithelial cells, can become an important source of LTs during an inflammatory response.

Like PGE 2 , the effects of LTs are mediated by signaling through $G$ protein-coupled receptors. Among the receptors for cysLTs, two have been thoroughly characterized. The cysLT1 receptor binds $\mathrm{LTD}_{4}$ with high affinity and binds $\mathrm{LTC}_{4}$ and $\mathrm{LTE}_{4}$ with lower affinities [16]. The cysLT2 receptor binds $\mathrm{LTC}_{4}$ and $\mathrm{LTD}_{4}$ with equal affinity. A number of studies have alluded to the existence of additional cysLTR subtypes, although these have yet to be characterized [17]. The chemoattractant and proinflammatory effects of $\mathrm{LTB}_{4}$ are mediated by the high-affinity $B$ leukotriene receptor 1 (BLT1). A second receptor, B leukotriene receptor 2 (BLT2), binds $\mathrm{LTB}_{4}$ with lower affinity, but its biological function remains poorly understood [18]. Studies in transfected cell lines have shown that the four LT receptors can couple to both $\mathrm{G} \alpha_{i}$ and $\mathrm{G} \alpha_{q}$ proteins to decrease cAMP and increase intracellular $\mathrm{Ca}^{2+}$, respectively [19-23]. Studies in primary cells have yielded differing results and the specific signaling programs initiated by GPCRs remain to be dissected [24]. Within the human lung, cysLT1 mRNA is expressed in epithelial cells, bronchial smooth muscle cells, interstitial macrophages, and the nasal mucosa. CysLT2 is expressed by bronchial smooth muscle cells, interstitial macrophages, and nasal mucosa [17]. Human BLT1 is expressed primarily in leukocytes and its expression can be altered in response to various inflammatory stimuli $[18,25]$. BLT2 is expressed 
more ubiquitously, with high mRNA expression detected in the spleen and low levels in most human tissues, including the lung [26].

\section{Eicosanoids and Immune Function}

3.1. Prostaglandin $E_{2}$. $\mathrm{PGE}_{2}$ regulates immune function in a myriad of ways that are likely to affect viral pathogenesis (Table 1). Widespread expression of COX-2 has been demonstrated in airway epithelial and resident inflammatory cells in the absence of overt inflammation, suggesting a role for COX-2 in regulation of human airway homeostasis [27]. High concentrations of COX products are present in the epithelial lining fluid of human airways, potentially playing a role in inhibiting lymphocyte activity and fibroblast proliferation in the absence of inflammation [28]. Additionally, constitutive secretion of $\mathrm{PGE}_{2}$ by airway epithelial cells contributes to modulation of DCs under homeostatic conditions [29]. PGE $_{2}$ can promote inflammation through vasodilatory mechanisms, yielding edema, warmth, erythema, and passive leukocyte recruitment. However, $\mathrm{PGE}_{2}$ is also capable of inhibiting neutrophil chemotaxis, phagocytosis, and bacterial killing $[30,31]$. $\mathrm{PGE}_{2}$ suppresses phagocytosis by nonalveolar monocytes/macrophages [32-35], and $\mathrm{PGE}_{2}$ inhibits alveolar macrophage (AM) phagocytosis via a mechanism that involves EP2 activation and increases in cAMP [36]. Bacterial killing and reactive oxygen intermediate generation by AMs is also inhibited by $\mathrm{PGE}_{2}$ in an EP2/EP4- and cAMPdependent manner [37].

The production of various pro-inflammatory cytokines and chemokines is inhibited in the presence of $\mathrm{PGE}_{2}[38$, 39], while production of the anti-inflammatory cytokine interleukin (IL)-10 is enhanced [40]. $\mathrm{PGE}_{2}$ suppresses production of the Th1 cytokines interferon (IFN) $-\gamma$ and IL-12, leading to a Th2-polarized environment $[41,42]$. However, a number of studies have also reported $\mathrm{PGE}_{2}$-mediated enhancement of Th1 cytokine secretion and differentiation in vivo $[43,44]$. The role of $\mathrm{PGE}_{2}$ is not strictly suppressive, as it has been shown to promote certain pathways in immune differentiation. For example, $\mathrm{PGE}_{2}$ can act on uncommitted B lymphocytes to promote isotype switching to IgE or IgG1 [45-47]. COX inhibitors inhibit antibody production in activated human B lymphocytes [48, 49]. $\mathrm{PGE}_{2}$ augments IL-17 production and Th17 differentiation by increasing IL-23 production in T cells and dendritic cells [44, 50-53], an activity that likely occurs via EP2- and EP4mediated increases in cAMP $[54,55]$. Additionally, $\mathrm{PGE}_{2}$ enhances the production of the proinflammatory cytokine IL-6 by leukocytes [56] and airway epithelial cells [57]. $\mathrm{PGE}_{2}$ potently inhibits the production of a number of antimicrobial peptides (AMPs) such as human $\beta$-defensin by epithelial cells [58]. This effect of $\mathrm{PGE}_{2}$ is likely to be relevant for viral pathogenesis, because AMPs can inhibit the replication of viruses $[59,60]$.

3.2. Leukotrienes. The diverse effects of LTs on innate immunity have been reviewed elsewhere [61] and are briefly summarized in Table $1 . \mathrm{LTB}_{4}$ promotes neutrophil migration and survival $[62,63]$ and enhances neutrophil granule enzyme secretion [64] and superoxide anion generation $[65,66]$. $\mathrm{T}$ lymphocyte recruitment to sites of inflammation can be induced by $\mathrm{LTB}_{4}[67-70]$. In addition to neutrophil and $\mathrm{T}$ cell trafficking, $\mathrm{LTB}_{4}$ can promote the migration of dendritic cells (DCs) in vitro [71] and to draining lymph nodes as mice deficient in BLT1/2 show reduced DC migration [72]. Both cysLTs and $\mathrm{LTB}_{4}$ can enhance Fcy receptor-mediated phagocytosis by AMs, though by different mechanisms $[24,73,74] . \mathrm{LTB}_{4}$ induces antimicrobial peptide release from neutrophils in vivo, in some cases inhibiting viral replication [75-77]. Lung generation of the proinflammatory cytokine TNF- $\alpha$ is enhanced by $\mathrm{LTB}_{4}$ [78]. A number of studies have reported that $\mathrm{LTB}_{4}$ acts synergistically with IL-4 to induce activation, proliferation, and differentiation of human B lymphocytes [79-81], although a separate study reported that 5-LO inhibitors actually enhanced B lymphocyte proliferation [82].

CysLTs can promote microvascular leak [11], enhance leukocyte survival $[83,84]$, and induce nitric oxide (NO) generation in neutrophils $[66,85]$. CysLTs induce DC chemotaxis to CCL19 and DC trafficking to lymph nodes is impaired in $\mathrm{LTC}_{4}$ transporter-deficient mice [12]. In addition, cysLTs have been suggested to play a role in allergen-induced DC migration from blood [86]. Addition of $\mathrm{LTD}_{4}$ to activated B lymphocytes leads to a modest upregulation of IgE and IgG production [87]. CysLTs also play a role in regulation of a pulmonary $\mathrm{Th} 2$ response as mice deficient in $\mathrm{LTC}_{4}$ synthase showed reduced Th2 cytokine mRNA expression and Ag-specific IgE and IgG1 in the lung [88]. CysLTs are recognized as important mediators in the pathogenesis of asthma by their ability to promote airway microvascular permeability, mucus secretion, and smooth muscle contraction [89-93].

The prostaglandins and leukotrienes modulate many host immune responses that are important contributors to viral pathogenesis, such as cytokine signaling, neutrophil and macrophage phagocytosis, trafficking and activation of DCs and $\mathrm{T}$ cells, and antibody production by B cells.

\section{Eicosanoids and Respiratory Viruses}

4.1. Influenza. Influenza infections account for over 200,000 hospitalizations annually in the USA [94]. In addition to hospitalizations, influenza is also associated with a substantial number of outpatient visits each year, causing considerable healthcare burden and economic costs. Influenza upregulates COX-2 expression both in vitro and in vivo, and it has been suggested that COX hyperinduction contributes to the exaggerated cytokine response observed in severe human H5N1 infections [95-97]. Alteration of the COX pathway has contrasting effects on inflammatory responses to influenza virus depending on the model of pharmacologic inhibition (COX-1- or COX-2-specific or dual inhibition) or of genetic deficiency. Treatment of influenza-infected mice with celecoxib, a selective COX-2 inhibitor, did not significantly affect viral titers or disease severity, although treatment did suppress production in the lung of the proinflammatory cytokines tumor necrosis factor- (TNF-) $\alpha$, IL-6 and granulocyte-colony stimulating 
TABLE 1: Effects of $\mathrm{PGE}_{2}$ and leukotrienes on immune function.

\begin{tabular}{|c|c|c|c|}
\hline & $\mathrm{PGE}_{2}$ & $\mathrm{LTB}_{4}$ & cysLTs \\
\hline Neutrophils & $\begin{array}{l}\text { Inhibits neutrophil } \\
\text { chemotaxis, phagocytosis, and } \\
\text { bacterial killing }\end{array}$ & $\begin{array}{l}\text { Promotes neutrophil } \\
\text { chemotaxis, ROS } \\
\text { generation, and survival }\end{array}$ & $\begin{array}{l}\text { Induces NO generation in } \\
\text { neutrophils }\end{array}$ \\
\hline Macrophages & $\begin{array}{l}\text { Inhibits AM phagocytosis, } \\
\text { ROS generation, and bacterial } \\
\text { killing }\end{array}$ & Enhances AM phagocytosis & Enhance AM phagocytosis \\
\hline $\mathrm{T}$ cells & Promotes Th17 differentiation & Induces $\mathrm{T}$ cell recruitment & Enhances Th2 response \\
\hline $\begin{array}{l}\text { B cells/Antibody } \\
\text { Production }\end{array}$ & $\begin{array}{l}\text { Promotes isotype switching to } \\
\text { IgE and IgG1 }\end{array}$ & $\begin{array}{l}\text { Induces activation, } \\
\text { differentiation, and } \\
\text { proliferation of B cells }\end{array}$ & $\begin{array}{l}\text { Upregulate IgE and IgG1 } \\
\text { production by B cells }\end{array}$ \\
\hline Dendritic Cells & Varies & Promotes DC migration & Promotes DC migration \\
\hline \multirow[t]{2}{*}{ Cytokines } & $\begin{array}{l}\text { Suppresses IFN- } \gamma \text { and IL-12 } \\
\text { production }\end{array}$ & $\begin{array}{l}\text { Enhances TNF- } \alpha \\
\text { production }\end{array}$ & $\begin{array}{l}\text { Enhances IL-5, IL-13, and } \\
\text { eotaxin expression }\end{array}$ \\
\hline & $\begin{array}{l}\text { Enhances IL-10 and IL-6 } \\
\text { production }\end{array}$ & & \\
\hline Antimicrobial Peptides & $\begin{array}{l}\text { Inhibits AMP production by } \\
\text { epithelial cells }\end{array}$ & $\begin{array}{l}\text { Induces AMP production } \\
\text { by neutrophils }\end{array}$ & Unknown \\
\hline
\end{tabular}

factor (G-CSF) [98]. In contrast, influenza infection of mice genetically deficient in COX-2 resulted in reduced mortality, inflammation, and cytokine responses compared to infection of wild-type control [99]. Peak lung viral titers were significantly elevated in COX- $2^{-1-}$ mice but returned to levels seen in wild-type mice by day 6 , suggesting a role for COX-2 in controlling early viral replication but not in virus clearance. Interestingly, levels of $\mathrm{PGE}_{2}$ in influenzainfected COX $-2^{-1-}$ mice were equivalent to levels measured in infected wild-type mice. The lack of $\mathrm{PGE}_{2}$ deficiency in COX $-2^{-/-}$mice could be due to compensatory upregulation of COX-1 activity, as has been described before [100].

Mice infected with highly virulent $\mathrm{H} 5 \mathrm{~N} 1$ and treated with a combination of celecoxib, the neuraminidase inhibitor zanamivir, and mesalazine (an aminosalicylate drug that exhibits weak 5-LO and COX inhibition [101]) showed significantly improved survival even when treatment was delayed 48 hours [102]. The beneficial effect of celecoxib and mesalazine likely stemmed from their effects on immunopathology, as mice treated with triple therapy had similar viral loads as those treated with zanamivir alone. Triple therapy significantly reduced levels of the proinflammatory cytokines IL-6, TNF- $\alpha$, and IFN- $\gamma$.

Another group treated influenza-infected mice with paracetamol (acetominophen), a selective inhibitor of COX2 [103, 104]. Paracetamol-treated mice had improved lung function, and reduced immunopathology compared to control mice. A separate group of mice treated with celecoxib also showed improvements in cellular infiltrates, lung function and pathology. However, the degree of improvement was generally less than that seen in paracetamol-treated mice. In contrast to mice genetically deficient in COX-2 [99], paracetamol- and celecoxib-treated mice had viral loads equivalent to those in untreated control mice. Virus-specific $\mathrm{CD}^{+}$and $\mathrm{CD}^{+} \mathrm{T}$ cell numbers were not altered in treated mice, and treatment with paracetamol or celecoxib did not interfere with the establishment of protective immunity to a second infection with a different influenza subtype.

The significantly increased viral titers seen in $\mathrm{COX}-2^{-/-}$ mice but not observed in mice treated with COX-2 inhibitors could be due to a functional defect in innate immunity, as COX products are known to be involved in modulating the innate immune response [105]. In addition, $\mathrm{COX}-2^{-/-}$ mice have a complete loss of COX-2 activity, whereas mice treated with inhibitors still retain some COX-2 activity due to insufficient inhibition by the drug. COX $-2^{-/-}$mice had levels of $\mathrm{PGE}_{2}$ in bronchoalveolar lavage (BAL) fluid similar to wild-type mice, suggesting that the effects of COX-2 deficiency in this model may not be due to lack of $\mathrm{PGE}_{2}$. As COX-2 $2^{-1-}$ deficiency is likely to affect the production of other prostaglandins (such as TXA $2, \mathrm{PGD}_{2}, \mathrm{PGF}_{2}$, and $\mathrm{PGI}_{2}$ ), it is possible that decreased levels of one of the other COX products are responsible for increased survival.

Influenza infection upregulates 5-LO expression and/or levels of LTs in cell lines as well as in lungs of infected mice and humans [106-108]. However, few studies have examined influenza infection in the context of altered 5-LO production (either due to genetic deficiency or pharmacologic inhibition). One study has reported a beneficial effect of exogenous $\mathrm{LTB}_{4}$ administration during influenza infection of mice [75]. Mice treated daily with $\mathrm{LTB}_{4}$ had significantly reduced lung viral loads. The lungs of $\mathrm{LTB}_{4}$-treated mice showed increased levels of multiple antimicrobial peptides, decreased inflammatory cell infiltration, and partially restored lung architecture. The antiviral effect of $\mathrm{LTB}_{4}$ was mediated by neutrophils and the high-affinity BLT1 receptor, as viral loads were unaffected in neutrophil-depleted or BLT1-deficient mice. $\mathrm{LTB}_{4}$ treatment of primary human neutrophils in this study induced antimicrobial peptide release and decreased influenza titers, demonstrating that the effects of $\mathrm{LTB}_{4}$ on neutrophils are similar in both mice and humans. This is in agreement with another study, in which human 
neutrophils treated with $\mathrm{LTB}_{4}$ showed significantly more myeloperoxidase (MPO) activity and $\alpha$-defensin production than untreated cells, and LTB $_{4}$-treated neutrophils had enhanced virucidal activity against influenza virus, human coronavirus, and RSV [109]. The role of cysLTs during influenza infection has yet to be defined in detail. Enhanced levels of cysLTs seen in COX-2 $2^{-/}$mice infected with influenza are associated with increased survival [99], but whether the decreased mortality in COX-2-deficient mice is directly due to cysLTs in this model is unknown.

The beneficial effects of COX-2 deficiency may also be due to shunting of released AA to the 5-LO pathway. A number of reports suggest that COX inhibitors enhance production of LTs $[110,111]$. Indeed, COX $-2^{-/-}$mice showed higher BAL fluid levels of cysLTs than wild-type mice following infection with influenza. However, in mice treated with a combination of zanamivir, celecoxib, and mesalazine, increased survival was associated with lower LT levels and higher $\mathrm{PGE}_{2}$ levels in the treated mice compared to wild type. The discrepancies in COX and 5-LO products in these models may reflect the different pathophysiology of the influenza strains used. Perhaps increased LT production during severe $\mathrm{H} 5 \mathrm{~N} 1$ infection promotes inflammation and local tissue damage, while $\mathrm{PGE}_{2}$ provides a balancing protective influence. In contrast, during infection with the less virulent $\mathrm{H} 3 \mathrm{~N} 2$ virus, enhanced LT production may contribute to virus clearance without a detrimental effect on host inflammation. However, in the case of either virus lower levels of the proinflammatory cytokines IL-6, TNF- $\alpha$, and IFN- $\gamma$ were correlated with decreased morbidity and increased survival. Other differences in the studies could be accounted for by differences in virus subtype, virus inoculum, mouse strain, or drug dose and delivery method. However, partial COX inhibition by pharmacologic intervention appears to be beneficial in reducing immunopathology while still controlling viral replication during influenza infection in mice.

4.2. Respiratory Syncytial Virus. Respiratory syncytial virus (RSV) is the leading cause of bronchiolitis and pneumonia in infants $[112,113]$. RSV is also a significant pathogen in the elderly population, particularly those living in long-term care facilities or with underlying cardiopulmonary disease [114]. The immunocompromised are at risk for severe RSV infection, with mortality rates of up to $80 \%$ reported for RSV pneumonia [115]. RSV induces $\mathrm{PGE}_{2}$ release in vitro, in animal models, and in lungs of infants with RSV bronchiolitis [116-119]. Treatment with COX inhibitors reduces RSV replication in vitro and diminishes immunopathology in vivo. Blocking PG production with NS-398, celecoxib, or the $\mathrm{CPLA}_{2}$ inhibitor pyrrophenone reduced virus particle production in the A549 airway epithelial cell line [116]. COX inhibition also reduced transcription and production of the proinflammatory cytokines IL-8 and RANTES (CCL5). RSVinduced activation of interferon regulatory factor (IRF) and $\mathrm{NF}-\kappa \mathrm{B}$ activation were suppressed by a high concentration of celecoxib. Another study demonstrated that the nonselective COX inhibitor indomethacin decreased lung histopathology in RSV-infected cotton rats, but COX inhibition did not significantly affect viral replication [117].

RSV also induces production of $\mathrm{LTB}_{4}$ and cysLTs in both animal models and infants afflicted with RSV bronchiolitis [119-125]. LT concentrations during RSV infection have been correlated with development of symptoms and in some reports are associated with disease severity $[107,122$, $126,127]$. Treatment of RSV-infected mice with the 5-LO inhibitor zileuton reduced inflammatory cell numbers in the lung, prevented RSV-induced weight loss, and decreased RSV-induced airway constriction [122]. Viral titers were somewhat lower in the lungs of zileuton-treated mice, although the difference was not statistically significant. Even when administered after the emergence of respiratory symptoms, zileuton reduced airway resistance and weight loss compared to untreated mice. Treatment with the cysLTR1 antagonist MK-571 decreased RSV-induced airway hyperreactivity (AHR) [121]. In contrast to treatment with zileuton, MK-571 did not affect inflammatory cell recruitment or production of IL- 4 and IFN- $\gamma$ in RSV-infected mice. A possible effect of MK-571 on viral titers was not examined in this study.

Similar to highly virulent influenza H5N1, successful treatment of RSV infection may require the use of an antiviral agent in combination with an anti-inflammatory agent that limits immunopathology. In support of this, treatment of RSV-infected cotton rats with the RSV-specific humanized monoclonal antibody palivizumab and a glucocorticoid resulted in enhanced clearance of RSV and limited lung histopathology compared to controls [128]. Further support comes from a model of pneumonia virus of mice (PVM), a paramyxovirus that is a close phylogenetic relative of RSV. PVM infection increased levels of cysLTs in the lung [129]. In this model, administration of either the cysLT1 antagonist montelukast or the nucleoside analog ribavirin did not affect disease severity. However, combined therapy of montelukast with ribavirin substantially decreased morbidity and mortality of PVM-infected mice.

Administration of montelukast during primary RSV infection prevented enhanced AHR, airway eosinophil recruitment, and mucus overproduction upon reinfection [120]. Montelukast administered only during secondary infection did not affect this enhanced response. Previous studies have shown that LTs are only transiently elevated during the acute phase of infection and that levels drop to baseline shortly after [130]. This suggests that LT inhibitors may have a beneficial effect during the early phase of infection but may no longer be useful as treatment for the long-term airway dysfunction observed after RSV infection when LT levels are no longer elevated.

The above reports demonstrate a beneficial effect of 5LO product inhibitors or cysLT1 receptor antagonists during primary infection with RSV. However, the studies in animal models used pharmacologic agents given to mice starting on the day before infection, whereas treatment in humans is typically initiated later during the course of infection after the emergence of symptoms. Delaying zileuton treatment until 3 days post infection, after respiratory symptoms emerged, still reduced clinical signs during primary RSV infection in 
mice. However, there have been conflicting results when 5LO inhibitors and cysLT antagonists were used as treatment in children with RSV bronchiolitis. One study suggested a beneficial effect of the cysLTR1 antagonist montelukast on lung symptoms after RSV bronchiolitis [131], but further studies have failed to corroborate these findings [132-134]. To our knowledge, there are no human studies that examine prophylactic administration of 5-LO pathway inhibitors or receptor antagonists to high-risk children. Further studies are needed to define the role of LT inhibitors in patients with primary RSV infection and in those experiencing persistent airway dysfunction after RSV.

While many viruses are capable of causing respiratory infections, relatively little is known about the contributions made by eicosanoids to the pathogenesis of respiratory viruses other than influenza and RSV. Rhinovirus (RV) infection increases expression of 5-LO, FLAP, and COX-2 in human bronchial cells [135]. In addition, cysLT levels in BAL fluid are increased upon rhinovirus infection in humans and correlate with emergence of upper respiratory symptoms $[107,135]$. Adenovirus induces COX-2 expression and $\mathrm{PGE}_{2}$ release in murine fibroblasts [136] and in human primary synovial fibroblasts [137]. Additional studies are necessary to examine adenovirus-induced PG production in lungrelevant cell types, but in vivo studies of human adenovirus pathogenesis are limited by the strict species specificity of adenoviruses. Using mouse adenovirus type 1 to study the pathogenesis of adenovirus respiratory infection [138] will provide a useful tool to define the roles of eicosanoids to adenovirus respiratory infection.

Human cytomegalovirus (HCMV) can also cause respiratory infections, although symptomatic disease is uncommon in immunocompetent individuals [139]. HCMV induces 5-LO expression and $\mathrm{LTB}_{4}$ production [140] in vascular smooth muscle cells as well as COX-2 expression and $\mathrm{PGE}_{2}$ production in fibroblasts [141]. COX-2 inhibition reduces levels of the immediate-early $2 \mathrm{mRNA}$ and protein in addition to viral DNA replication and transcription of some early and late mRNAs. Treatment of HCMVinfected fibroblasts with COX inhibitors inhibits cell-to-cell spread of virus [142]. Of note, while many reports with other viruses have shown inhibition of viral replication or gene transcription by COX inhibitors at non-physiologic concentrations, these results with HCMV were obtained with concentrations of COX inhibitors that are achievable in human plasma. Although few studies have examined the effect of 5-LO products on HCMV pathogenesis, one study reported that exogenous $\mathrm{LTB}_{4}$ inhibited reactivation of CMV following allogeneic bone marrow transplantation (BMT) in mice, demonstrating a beneficial effect for this LT [143].

\section{Common Themes}

From the data summarized above (see also Table 2), it is clear that the effect of COX or 5-LO inhibition or antagonism of cysLT receptors on host responses to respiratory viral infection is variable and in some cases may be pathogen- and/or model-specific. In general, COX inhibition or deficiency is associated with less exuberant inflammation and in some cases improved survival. COX products may play a role in controlling early viral replication, although this possible role is only evident for influenza infection in mice completely lacking COX-2 activity and not in mice treated with a COX-2 inhibitor. These data are consistent with the role of $\mathrm{PGE}_{2}$ as an immunomodulatory mediator, balancing proinflammatory actions with suppressive effects on innate and adaptive immune function. Inhibition of LT production or signaling during respiratory viral infection is associated with less inflammation accompanied by variable (but generally beneficial) effects on lung physiology. However, administration of exogenous $\mathrm{LTB}_{4}$ also blunted inflammatory responses to influenza virus in one study [75], suggesting that various 5-LO products may be differentially involved in promoting inflammation and affecting host immune responses to viral infection.

\section{Therapeutic Implications}

Respiratory viral infections cause substantial disease and are associated with significant morbidity, mortality, and healthcare utilization. Many antiviral drugs are available to treat infection with human immunodeficiency virus, and a smaller number of drugs such as acyclovir and ganciclovir are available to treat infections with herpesviruses such as herpes simplex virus, varicella zoster virus, and HCMV. In contrast, far fewer drugs are available to treat viruses that most frequently cause respiratory infections. Neuraminidase inhibitors such as oseltamivir and zanamavir can be used as prophylaxis to prevent infection by influenza virus or used to treat infection. Older drugs such as amantadine and rimantadine can also be used to prevent or treat influenza. However, the emergence of drug-resistant influenza strains has the potential to increasingly limit the utility of these drugs. The nucleoside analog cidofovir has been used to treat adenovirus infections, although it has substantial toxicities and no randomized clinical trials have been performed to show clinical benefit. Currently, there are no drugs that have consistently been shown to be safe and effective for the treatment of disease caused by infection with RSV, rhinovirus, human metapneumovirus, or other viruses that commonly cause respiratory infections.

Preventing virus-induced inflammation may serve as an important adjunct to any antiviral therapy. When antiviral drugs are not available, modulation of virus-induced inflammation by itself may serve as an effective strategy to treat disease caused by viruses. Drugs with the ability to modulate eicosanoid production, such as ibuprofen and acetaminophen, are already frequently used in patients with respiratory infections to alleviate fevers, myalgias, and nonspecific symptoms. Studies described above that show decreased virus-induced inflammation and increased survival in animals treated with an inhibitor of PG or LT synthesis or in PG- or LT-deficient animals support the potential benefit of this approach. Drugs that modulate eicosanoid production may be particularly useful to prevent or treat infections in patients with exaggerated eicosanoid production at baseline. For instance, exaggerated $\mathrm{PGE}_{2}$ production in the setting of bone marrow transplantation 
TABLE 2: Effects of $\mathrm{PGE}_{2}$ and Leukotrienes on respiratory syncytial virus and influenza infection.

\begin{tabular}{|c|c|c|c|}
\hline & \multicolumn{2}{|c|}{$\mathrm{PGE}_{2}$} & \multirow[t]{2}{*}{ Leukotrienes } \\
\hline & COX Inhibition & COX-2 Deficiency & \\
\hline \multirow{4}{*}{ RSV } & $\begin{array}{l}\text { Reduction in viral replication in } \\
\text { vitro }\end{array}$ & & $\begin{array}{l}\text { Reduction in pulmonary } \\
\text { inflammatory, weight loss, and }\end{array}$ \\
\hline & $\begin{array}{l}\text { Suppression of virus-induced } \\
\text { cytokine production in vitro }\end{array}$ & & $\begin{array}{l}\text { RSV-induced airway constriction in } \\
\text { mice treated with 5-LO inhibitor }\end{array}$ \\
\hline & $\begin{array}{l}\text { No effect on viral replication in the } \\
\text { lungs in vivo }\end{array}$ & & $\begin{array}{l}\text { CysLTR1 antagonism during primary } \\
\text { infection prevents enhanced AHR } \\
\text { upon reinfection }\end{array}$ \\
\hline & Decreased lung pathology in vivo & & $\begin{array}{l}\text { Decreased RSV-induced AHR but no } \\
\text { effect on cytokine production in mice } \\
\text { treated with cysLTR } 1 \text { antagonist }\end{array}$ \\
\hline \multirow{4}{*}{ Influenza } & $\begin{array}{l}\text { No effect on viral replication or } \\
\text { disease severity in micetreated with } \\
\text { celecoxib }\end{array}$ & $\begin{array}{l}\text { Decreased mortality, pulmonary } \\
\text { inflammation and cytokine } \\
\text { responses in COX }-2^{-/-} \text {mice }\end{array}$ & $\begin{array}{l}\text { Reduced lung viral loads and } \\
\text { decreased pulmonary inflammatory in } \\
\text { mice treated with exogenous } \mathrm{LTB}_{4}\end{array}$ \\
\hline & $\begin{array}{l}\text { Suppression of virus-induced } \\
\text { cytokine production in mice treated } \\
\text { with celecoxib }\end{array}$ & \multirow{3}{*}{$\begin{array}{l}\text { Increased viral titers in lungs of } \\
\text { COX- } 2^{-/-} \text {mice compared to } \\
\text { controls }\end{array}$} & \\
\hline & $\begin{array}{l}\text { Improved survival and reduced } \\
\text { proinflammatory cytokine levels in } \\
\text { mice treated with zanamivir, } \\
\text { celecoxib, and mesalazine }\end{array}$ & & \\
\hline & $\begin{array}{l}\text { Improved lung function and } \\
\text { reduced immunopathology in mice } \\
\text { treated with paracetamol }\end{array}$ & & \\
\hline
\end{tabular}

has been associated with increased susceptibility to bacterial infection that is linked to impaired neutrophil and macrophage phagocytosis and killing [144, 145]. Increased $\mathrm{PGE}_{2}$ production has been reported in humans with a variety of disease states including cancer [146], aging [147], HIV infection [148], malnutrition [149, 150], and stem cell and solid organ transplant recipients $[151,152]$, making the potential benefits of this approach more widespread.

Any therapy that involves modulation of eicosanoid production must consider the potential for deleterious effects on the development of adaptive immunity and subsequent protection from secondary infection. $\mathrm{PGE}_{2}$ plays an important role in optimal antibody synthesis, as COX inhibitors reduce antibody production in activated human B lymphocytes [48, 49]. In addition, mice genetically deficient in COX-2 produce significantly less IgM and IgG than wild-type mice [48]. There is evidence that COX-2 plays a role in potentiating antibody production in humans as well. Human volunteers challenged with RV showed increased nasal symptoms and a suppressed serum neutralizing antibody response when treated with aspirin or acetaminophen, suggesting a protective role for COX products in reducing symptoms and promoting an antibody response [153]. One large-scale study has been performed in which children were administered prophylactic paracetamol when receiving routine childhood vaccinations [154]. Antibody responses to several of the vaccine antigens were less robust in patients receiving prophylactic paracetamol. Evidence also exists that LTs, like $\mathrm{PGE}_{2}$, promote appropriate antibody responses [79-81, 87], but the effect of 5-LO inhibitors and receptor antagonists on antibody production has not yet been described.

\section{Conclusions}

Eicosanoids modulate many host immune responses that are important contributors to viral pathogenesis. It will be essential to better define mechanisms underlying the effects of eicosanoids on both innate and adaptive immune responses to respiratory viral infection in order to develop therapies with maximal anti-inflammatory benefit and minimal impact on protective immune responses. For instance, the use of specific receptor agonists or antagonists may eventually provide a better-tailored approach than inhibitors of PG or LT synthesis to treat patients with respiratory viral infections. In general terms, however, alteration of eicosanoid production or antagonism of eicosanoid receptors has the potential to serve as a useful treatment strategy for respiratory viral infections.

\section{Acknowledgments}

The authors would like to thank David Aronoff for helpful conversations and Beth Moore for helpful comments on the manuscript. Research in the Weinberg Laboratory is supported by NIH R01 AI083334. This article was made available as Open Access with the support of the University of Michigan COPE Fund, http://lib.umich.edu/cope. 


\section{References}

[1] K. J. Henrickson, S. Hoover, K. S. Kehl, and W. Hua, "National disease burden of respiratory viruses detected in children by polymerase chain reaction," Pediatric Infectious Disease Journal, vol. 23, no. 1, pp. S11-S18, 2004.

[2] A. T. Pavia, "Viral infections of the lower respiratory tract: old viruses, new viruses, and the role of diagnosis," Clinical Infectious Diseases, vol. 52, no. 4, supplement, pp. S284-S289, 2011.

[3] S. B. Greenberg, "Viral respiratory infections in elderly patients and patients with chronic obstructive pulmonary disease," American Journal of Medicine, vol. 112, no. 6, pp. 28S-32S, 2002.

[4] W. G. Nichols, A. J. Peck Campbell, and M. Boeckh, "Respiratory viruses other than influenza virus: impact and therapeutic advances," Clinical Microbiology Reviews, vol. 21, pp. 274-290, 2008.

[5] C. D. Funk, "Prostaglandins and leukotrienes: advances in eicosanoid biology," Science, vol. 294, no. 5548, pp. 18711875, 2001.

[6] N. V. Chandrasekharan, H. Dai, K. L. T. Roos et al., "COX3 , a cyclooxygenase-1 variant inhibited by acetaminophen and other analgesic/antipyretic drugs: cloning, structure, and expression," Proceedings of the National Academy of Sciences of the United States of America, vol. 99, no. 21, pp. 13926-13931, 2002.

[7] B. Kis, J. A. Snipes, and D. W. Busija, "Acetaminophen and the cyclooxygenase-3 puzzle: sorting out facts, fictions, and uncertainties," Journal of Pharmacology and Experimental Therapeutics, vol. 315, no. 1, pp. 1-7, 2005.

[8] G. Reid, P. Wielinga, N. Zelcer et al., "The human multidrug resistance protein MRP4 functions as a prostaglandin efflux transporter and is inhibited by nonsteroidal anti inflammatory drugs," Proceedings of the National Academy of Sciences of the United States of America, vol. 100, no. 16, pp. 9244-9249, 2003.

[9] A. Watabe, Y. Sugimoto, A. Honda et al., "Cloning and expression of cDNA for a mouse EP1 subtype of prostaglandin E receptor," Journal of Biological Chemistry, vol. 268, no. 27, pp. 20175-20178, 1993.

[10] S. Narumiya, Y. Sugimoto, and F. Ushikubi, "Prostanoid receptors: structures, properties, and functions," Physiological Reviews, vol. 79, no. 4, pp. 1193-1226, 1999.

[11] K. Okunishi and M. Peters-Golden, "Leukotrienes and airway inflammation," Biochimica et Biophysica Acta, vol. 1810, no. 11, pp. 1096-1102, 2011.

[12] D. F. Robbiani, R. A. Finch, D. Jäger, W. A. Muller, A. C. Sartorelli, and G. J. Randolph, "The leukotriene C4 transporter MRP1 regulates CCL19 (MIP-3 $\beta$, ELC)-dependent mobilization of dendritic cells to lymph nodes," Cell, vol. 103, no. 5, pp. 757-768, 2000.

[13] A. J. Jame, P. M. Lackie, A. M. Cazaly et al., "Human bronchial epithelial cells express an active and inducible biosynthetic pathway for leukotrienes B4 and C4," Clinical and Experimental Allergy, vol. 37, no. 6, pp. 880-892, 2007.

[14] A. J. James, J. F. Penrose, A. M. Cazaly, S. T. Holgate, and A. P. Sampson, "Human bronchial fibroblasts express the 5lipoxygenase pathway," Respiratory Research, vol. 7, article 102, 2006.

[15] A. Sala, G. Folco, and R. C. Murphy, "Transcellular biosynthesis of eicosanoids," Pharmacological Reports, vol. 62, no. 3, pp. 503-510, 2010.
[16] Y. Kanaoka and J. A. Boyce, "Cysteinyl leukotrienes and their receptors: cellular distribution and function in immune and inflammatory responses," Journal of Immunology, vol. 173, no. 3, pp. 1503-1510, 2004.

[17] V. Capra, M. D. Thompson, A. Sala, D. E. Cole, G. Folco, and G. E. Rovati, "Cysteinyl-leukotrienes and their receptors in asthma and other inflammatory diseases: critical update and emerging trends," Medicinal Research Reviews, vol. 27, no. 4, pp. 469-527, 2007.

[18] A. M. Tager and A. D. Luster, "BLT1 and BLT2: the leukotriene B4 receptors," Prostaglandins Leukotrienes and Essential Fatty Acids, vol. 69, no. 2-3, pp. 123-134, 2003.

[19] K. R. Lynch, G. P. O’Neill, Q. Liu et al., “Characterization of the human cysteinyl leukotriene CysLT1 receptor," Nature, vol. 399, no. 6738, pp. 789-793, 1999.

[20] T. Yokomizo, T. Izumi, K. Chang, Y. Takuwa, and T. Shimizu, "A G-protein-coupled receptor for leukotriene B4 that mediates chemotaxis," Nature, vol. 387, no. 6633, pp. 620-624, 1997.

[21] H. M. Sarau, R. S. Ames, J. Chambers et al., "Identification, molecular cloning, expression, and characterization of a cysteinyl leukotriene receptor," Molecular Pharmacology, vol. 56, no. 3, pp. 657-663, 1999.

[22] K. Pollock and J. Creba, "Leukotriene D4 induced calcium changes in U937 cells may utilize mechanisms additional to inositol phosphate production that are pertussis toxin insensitive but are blocked by phorbol myristate acetate," Cellular Signalling, vol. 2, no. 6, pp. 563-568, 1990.

[23] S. T. Crooke, M. Mattern, H. M. Sarau et al., "The signal transduction system of the leukotriene D4 receptor," Trends in Pharmacological Sciences, vol. 10, no. 3, pp. 103-107, 1989.

[24] C. M. Peres, D. M. Aronoff, C. H. Serezani, N. Flamand, L. H. Faccioli, and M. Peters-Golden, "Specific leukotriene receptors couple to distinct $G$ proteins to effect stimulation of alveolar macrophage host defense functions," Journal of Immunology, vol. 179, no. 8, pp. 5454-5461, 2007.

[25] A. Pettersson, A. Sabirsh, J. Bristulf et al., "Pro- and antiinflammatory substances modulate expression of the leukotriene B4 receptor, BLT1, in human monocytes," Journal of Leukocyte Biology, vol. 77, no. 6, pp. 1018-1025, 2005.

[26] T. Yokomizo, K. Kato, K. Terawaki, T. Izumi, and T. Shimizu, "A second leukotriene B4receptor, BLT2: a new therapeutic target in inflammation and immunological disorders," Journal of Experimental Medicine, vol. 192, no. 3, pp. 421-431, 2000.

[27] D. N. Watkins, D. J. Peroni, J. C. Lenzo, D. A. Knight, M. J. Garlepp, and P. J. Thompson, "Expression and localization of COX-2 in human airways and cultured airway epithelial cells," European Respiratory Journal, vol. 13, no. 5, pp. 9991007, 1999.

[28] T. Ozaki, S. I. Rennard, and R. G. Crystal, "Cyclooxygenase metabolites are compartmentalized in the human lower respiratory tract," Journal of Applied Physiology, vol. 62, no. 1, pp. 219-222, 1987.

[29] L. M. Schmidt, M. G. Belvisi, K. A. Bode et al., "Bronchial epithelial cell-derived prostaglandin E2 dampens the reactivity of dendritic cells," Journal of Immunology, vol. 186, no. 4, pp. 2095-2105, 2011.

[30] D. M. Aronoff, C. Canetti, C. H. Serezani, M. Luo, and M. Peters-Golden, "Cutting edge: macrophage inhibition by cyclic AMP (cAMP)—differential roles of protein kinase A 
and exchange protein directly activated by cAMP-1," Journal of Immunology, vol. 174, no. 2, pp. 595-599, 2005.

[31] R. A. Armstrong, "Investigation of the inhibitory effects of PGE2 and selective EP agonists on chemotaxis of human neutrophils," British Journal of Pharmacology, vol. 116, no. 7, pp. 2903-2908, 1995.

[32] R. L. Oropeza-Rendon, V. Speth, and G. Hiller, "Prostaglandin E1 reversibly induces morphological changes in macrophages and inhibits phagocytosis," Experimental Cell Research, vol. 119, no. 2, pp. 365-371, 1979.

[33] E. Fernandez-Repollet, R. S. Mittler, S. Tiffany, and A. Schwartz, "In vivo effects of prostaglandin E2 and arachidonic acid on phagocytosis of fluorescent methacrylate microbeads by rat peritoneal macrophages," Journal of Histochemistry and Cytochemistry, vol. 30, no. 5, pp. 466-470, 1982.

[34] J. Davidson, A. Kerr, K. Guy, and D. Rotondo, "Prostaglandin and fatty acid modulation of Escherichia coli O157 phagocytosis by human monocytic cells," Immunology, vol. 94, no. 2, pp. 228-234, 1998.

[35] B. J. Canning, R. R. Hmieleski, E. W. Spannhake, and G. J. Jakab, "Ozone reduces murine alveolar and peritoneal macrophage phagocytosis: the role of prostanoids," American Journal of Physiology, vol. 261, no. 4, pp. L277-L282, 1991.

[36] D. M. Aronoff, C. Canetti, and M. Peters-Golden, "Prostaglandin E2 inhibits alveolar macrophage phagocytosis through an E-prostanoid 2 receptor-mediated increase in intracellular cyclic AMP," Journal of Immunology, vol. 173, no. 1, pp. 559-565, 2004.

[37] C. H. Serezani, J. Chung, M. N. Ballinger, B. B. Moore, D. M. Aronoff, and M. Peters-Golden, "Prostaglandin E2 suppresses bacterial killing in alveolar macrophages by inhibiting NADPH oxidase," American Journal of Respiratory Cell and Molecular Biology, vol. 37, no. 5, pp. 562-570, 2007.

[38] D. M. Aronoff, J. K. Carstens, G. H. Chen, G. B. Toews, and M. Peters-Golden, "Differences between macrophages and dendritic cells in the cyclic AMP-dependent regulation of lipopolysaccharide-induced cytokine and chemokine synthesis," Journal of Interferon and Cytokine Research, vol. 26, no. 11, pp. 827-833, 2006.

[39] S. L. Kunkel, M. Spengler, M. A. May, R. Spengler, J. Larrick, and D. Remick, "Prostaglandin E2 regulates macrophagederived tumor necrosis factor gene expression," Journal of Biological Chemistry, vol. 263, no. 11, pp. 5380-5384, 1988.

[40] H. Harizi, M. Juzan, V. Pitard, J. F. Moreau, and N. Gualde, "Cyclooxygenase-2-issued prostaglandin E2 enhances the production of endogenous IL-10, which down-regulates dendritic cell functions," Journal of Immunology, vol. 168, no. 5, pp. 2255-2263, 2002.

[41] M. Betz and B. S. Fox, "Prostaglandin E2 inhibits production of Th1 lymphokines but not of Th2 lymphokines," Journal of Immunology, vol. 146, no. 1, pp. 108-113, 1991.

[42] F. G. M. Snijdewint, P. Kalinski, E. A. Wierenga, J. D. Bos, and M. L. Kapsenberg, "Prostaglandin E2 differentially modulates cytokine secretion profiles of human T helper lymphocytes," Journal of Immunology, vol. 150, no. 12, pp. 5321-5329, 1993.

[43] D. Bloom, N. Jabrane-Ferrat, L. Zeng et al., "Prostaglandin E2 enhancement of interferon- $\gamma$ production by antigenstimulated type 1 helper T cells," Cellular Immunology, vol. 194, no. 1, pp. 21-27, 1999.

[44] C. Yao, D. Sakata, Y. Esaki et al., "Prostaglandin E2-EP4 signaling promotes immune inflammation through TH1 cell differentiation and TH17 cell expansion," Nature Medicine, vol. 15, no. 6, pp. 633-640, 2009.

[45] R. L. Roper, D. M. Brown, and R. P. Phipps, "Prostaglandin E2 promotes B lymphocyte Ig isotype switching to IgE," Journal of Immunology, vol. 154, no. 1, pp. 162-170, 1995.

[46] E. R. Fedyk and R. P. Phipps, "Prostaglandin E2 receptors of the EP2 and EP4 subtypes regulate activation and differentiation of mouse B lymphocytes to IgE-secreting cells," Proceedings of the National Academy of Sciences of the United States of America, vol. 93, no. 20, pp. 10978-10983, 1996.

[47] R. L. Roper, B. Graf, and R. P. Phipps, "Prostaglandin E2 and cAMP promote B lymphocyte class switching to IgG1," Immunology Letters, vol. 84, no. 3, pp. 191-198, 2002.

[48] E. P. Ryan, S. J. Pollack, T. I. Murant, S. H. Bernstein, R. E. Felgar, and R. P. Phipps, "Activated human B lymphocytes express cyclooxygenase- 2 and cyclooxygenase inhibitors attenuate antibody production," Journal of Immunology, vol. 174, no. 5, pp. 2619-2626, 2005.

[49] S. Bancos, M. P. Bernard, D. J. Topham, and R. P. Phipps, "Ibuprofen and other widely used non-steroidal antiinflammatory drugs inhibit antibody production in human cells," Cellular Immunology, vol. 258, no. 1, pp. 18-28, 2009.

[50] T. Khayrullina, J. H. Yen, H. Jing, and D. Ganea, "In vitro differentiation of dendritic cells in the presence of prostaglandin E2 alters the IL-12/IL-23 balance and promotes differentiation of Thl7 cells," Journal of Immunology, vol. 181, no. 1, pp. 721-735, 2008.

[51] G. Napolitani, E. V. Acosta-Rodriguez, A. Lanzavecchia, and F. Sallusto, "Prostaglandin E2 enhances Th17 responses via modulation of IL-17 and IFN- $\gamma$ production by memory CD4+ T cells," European Journal of Immunology, vol. 39, no. 5, pp. 1301-1312, 2009.

[52] A. F. Sheibanie, I. Tadmori, H. Jing, E. Vassiliou, and D. Ganea, "Prostaglandin E2 induces IL-23 production in bone marrow-derived dendritic cells," FASEB Journal, vol. 18, no. 11, pp. 1318-1320, 2004.

[53] C. Chizzolini, R. Chicheportiche, M. Alvarez et al., "Prostaglandin E2 synergistically with interleukin-23 favors human Th17 expansion," Blood, vol. 112, no. 9, pp. 36963703, 2008.

[54] M. Schnurr, T. Toy, A. Shin, M. Wagner, J. Cebon, and E. Maraskovsky, "Extracellular nucleotide signaling by P2 receptors inhibits IL-12 and enhances IL-23 expression in human dendritic cells: a novel role for the cAMP pathway," Blood, vol. 105, no. 4, pp. 1582-1589, 2005.

[55] K. Boniface, K. S. Bak-Jensen, Y. Li et al., "Prostaglandin E2 regulates Th17 cell differentiation and function through cyclic AMP and EP2/EP4 receptor signaling," Journal of Experimental Medicine, vol. 206, no. 3, pp. 535-548, 2009.

[56] J. M. McCoy, J. R. Wicks, and L. P. Audoly, "The role of prostaglandin E2 receptors in the pathogenesis of rheumatoid arthritis," Journal of Clinical Investigation, vol. 110, no. 5, pp. 651-658, 2002.

[57] S. Tavakoli, M. J. Cowan, T. Benfield, C. Logun, and J. H. Shelhamer, "Prostaglandin E2-induced interleukin-6 release by a human airway epithelial cell line," American Journal of Physiology, vol. 280, no. 1, pp. L127-L133, 2001.

[58] D. M. Aronoff, Y. Hao, J. Chung et al., "Misoprostol impairs female reproductive tract innate immunity against Clostridium sordellii," Journal of Immunology, vol. 180, no. 12, pp. 8222-8230, 2008.

[59] M. C. Carriel-Gomes, J. M. Kratz, M. A. Barracco, E. Bachére, C. R. M. Barardi, and C. M. O. Simões, "In vitro antiviral activity of antimicrobial peptides against herpes simplex 
virus 1, adenovirus, and rotavirus," Memorias do Instituto Oswaldo Cruz, vol. 102, no. 4, pp. 469-472, 2007.

[60] E. K. Nguyen, G. R. Nemerow, and J. G. Smithf, "Direct evidence from single-cell analysis that human $\alpha$-defensins block adenovirus uncoating to neutralize infection," Journal of Virology, vol. 84, no. 8, pp. 4041-4049, 2010.

[61] M. Peters-Golden, C. Canetti, P. Mancuso, and M. J. Coffey, "Leukotrienes: underappreciated mediators of innate immune responses," Journal of Immunology, vol. 174, no. 2, pp. 589-594, 2005.

[62] E. Lee, T. Lindo, N. Jackson et al., "Reversal of human neutrophil survival by leukotriene B4 receptor blockade and 5-lipoxygenase and 5-lipoxygenase activating protein inhibitors," American Journal of Respiratory and Critical Care Medicine, vol. 160, no. 6, pp. 2079-2085, 1999.

[63] A. W. Ford-Hutchinson, M. A. Bray, and M. V. Doig, "Leukotriene B, a potent chemokinetic and aggregating substance released from polymorphonuclear leukocytes," Nature, vol. 286, no. 5770, pp. 264-265, 1980.

[64] I. Hafstrom, J. Palmblad, and C. L. Malmsten, "Leukotriene B4: a stereospecific stimulator for release of lysosomal enzymes from neutrophils," FEBS Letters, vol. 130, no. 1, pp. 146-148, 1981.

[65] C. N. Serhan, A. Radin, J. E. Smolen, H. Korchak, B. Samuelsson, and G. Weissmann, "Leukotriene B4 is a complete secretagogue in human neutrophils: a kinetic analysis," Biochemical and Biophysical Research Communications, vol. 107, pp. 1006-1012, 1982.

[66] G. Lärfars, F. Lantoine, M. A. Devynck, J. Palmblad, and H. Gyllenhammar, "Activation of nitric oxide release and oxidative metabolism by leukotrienes B4, C4, and D4 in human polymorphonuclear leukocytes," Blood, vol. 93, no. 4, pp. 1399-1405, 1999.

[67] A. M. Tager, S. K. Bromley, B. D. Medoff et al., "Leukotriene B4 receptor BLT1 mediates early effector T cell recruitment," Nature Immunology, vol. 4, no. 10, pp. 982-990, 2003.

[68] V. L. Ott, J. C. Cambier, J. Kappler, P. Marrack, and B. J. Swanson, "Mast cell-dependent migration of effector CD8+ T cells through production of leukotriene B4," Nature Immunology, vol. 4, no. 10, pp. 974-981, 2003.

[69] M. F. De Souza Costa, R. De Souza-Martins, M. C. De Souza et al., "Leukotriene B4 mediates $\gamma \delta$ T lymphocyte migration in response to diverse stimuli," Journal of Leukocyte Biology, vol. 87, no. 2, pp. 323-332, 2010.

[70] K. Goodarzi, M. Goodarzi, A. M. Tager, A. D. Luster, and U. H. von Andrian, "Leukotriene B4 and BLT1 control cytotoxic effector T cell recruitment to inflamed tissues," Nature Immunology, vol. 4, no. 10, pp. 965-973, 2003.

[71] E. H. Shin, H. Y. Lee, and Y. S. Bae, "Leukotriene B4 stimulates human monocyte-derived dendritic cell chemotaxis," Biochemical and Biophysical Research Communications, vol. 348, no. 2, pp. 606-611, 2006.

[72] A. Del Prete, W. H. Shao, S. Mitola, G. Santoro, S. Sozzani, and B. Haribabu, "Regulation of dendritic cell migration and adaptive immune response by leukotriene B4 receptors: a role for LTB4 in up-regulation of CCR7 expression and function," Blood, vol. 109, no. 2, pp. 626-631, 2007.

[73] P. Mancuso and M. Peters-Golden, "Modulation of alveolar macrophage phagocytosis by leukotrienes is Fc receptormediated and protein kinase C-dependent," American Journal of Respiratory Cell and Molecular Biology, vol. 23, no. 6, pp. 727-733, 2000.
[74] C. Canetti, B. Hu, J. L. Curtis, and M. Peters-Golden, "Syk activation is a leukotriene B4-regulated event involved in macrophage phagocytosis of IgG-coated targets but not apoptotic cells," Blood, vol. 102, no. 5, pp. 1877-1883, 2003.

[75] E. Gaudreault and J. Gosselin, "Leukotriene B4 induces release of antimicrobial peptides in lungs of virally infected mice," Journal of Immunology, vol. 180, no. 9, pp. 6211-6221, 2008.

[76] E. Gaudreault and J. Gosselin, "Leukotriene B4-mediated release of antimicrobial peptides against cytomegalovirus is BLT1 dependent," Viral Immunology, vol. 20, no. 3, pp. 407420, 2007.

[77] L. Flamand, P. Borgeat, R. Lalonde, and J. Gosselin, "Release of anti-HIV mediators after administration of leukotriene B 4 to humans," Journal of Infectious Diseases, vol. 189, no. 11, pp. 2001-2009, 2004.

[78] G. Goldman, R. Welbourn, L. Kobzik, C. R. Valeri, D. Shepro, and H. B. Hechtman, "Lavage with leukotriene B4 induces lung generation of tumor necrosis factor- $\alpha$ that in turn mediates neutrophil diapedesis," Surgery, vol. 113, no. 3, pp. 297-303, 1993.

[79] K. A. Yamaoka, B. Dugas, N. Paul-Eugene, J. M. MenciaHuerta, P. Braquet, and J. P. Kolb, "Leukotriene B4 enhances IL-4-induced IgE production from normal human lymphocytes," Cellular Immunology, vol. 156, no. 1, pp. 124-134, 1994.

[80] K. A. Yamaoka, H. E. Claesson, and A. Rosen, "Leukotriene B4 enhances activation, proliferation, and differentiation of human B lymphocytes," Journal of Immunology, vol. 143, no. 6, pp. 1996-2000, 1989.

[81] B. Dugas, N. Paul-Eugene, J. Cairns et al., "Leukotriene B4 potentiates the expression and release of FceRII/CD23, and proliferation and differentiation of human B lymphocytes induced by IL-4," Journal of Immunology, vol. 145, no. 10, pp. 3406-3411, 1990.

[82] T. W. Behrens, L. G. Lum, E. A. Lianos, and J. S. Goodwin, "Lipoxygenase inhibitors enhance the proliferation of human B cells," Journal of Immunology, vol. 143, no. 7, pp. 22852294, 1989.

[83] M. J. Hébert, T. Takano, H. Holthöfer, and H. R. Brady, "Sequential morphologic events during apoptosis of human neutrophils: modulation by lipoxygenase-derived eicosanoids," Journal of Immunology, vol. 157, no. 7, pp. 3105-3115, 1996.

[84] E. Lee, T. Robertson, J. Smith, and S. Kilfeather, "Leukotriene receptor antagonists and synthesis inhibitors reverse survival in eosinophils of asthmatic individuals," American Journal of Respiratory and Critical Care Medicine, vol. 161, no. 6, pp. 1881-1886, 2000.

[85] H. H. H. W. Schmidt, R. Seifert, and E. Bohme, "Formation and release of nitric oxide from human neutrophils and HL60 cells induced by a chemotactic peptide, platelet activating factor and leukotriene B4," FEBS Letters, vol. 244, no. 2, pp. 357-360, 1989.

[86] K. Parameswaran, H. Liang, A. Fanat, R. Watson, D. P. Snider, and P. M. O'Byrne, "Role for cysteinyl leukotrienes in allergen-induced change in circulating dendritic cell number in asthma," Journal of Allergy and Clinical Immunology, vol. 114 , no. 1, pp. 73-79, 2004.

[87] J. Lamoureux, J. Stankova, and M. Rola-Pleszczynski, "Leukotriene D4 enhances immunoglobulin production in CD40activated human B lymphocytes," Journal of Allergy and Clinical Immunology, vol. 117, no. 4, pp. 924-930, 2006. 
[88] D. C. Kim, F. I. Hsu, N. A. Barrett et al., "Cysteinyl leukotrienes regulate $\mathrm{Th} 2$ cell-dependent pulmonary inflammation," Journal of Immunology, vol. 176, no. 7, pp. 4440-4448, 2006.

[89] S. T. Holgate, M. Peters-Golden, R. A. Panettieri et al., "Roles of cysteinyl leukotrienes in airway inflammation, smooth muscle function, and remodeling," Journal of Allergy and Clinical Immunology, vol. 111, no. 1, pp. S18-S36, 2003.

[90] S. E. Dahlén, P. Hedqvist, S. Hammarström, and B. Samuelsson, "Leukotrienes are potent constrictors of human bronchi," Nature, vol. 288, no. 5790, pp. 484-486, 1980.

[91] P. Montuschi and M. L. Peters-Golden, "Leukotriene modifiers for asthma treatment," Clinical and Experimental Allergy, vol. 40, no. 12, pp. 1732-1741, 2010.

[92] S. E. Dahlén, "Treatment of asthma with antileukotrienes: first line or last resort therapy?" European Journal of Pharmacology, vol. 533, no. 1-3, pp. 40-56, 2006.

[93] Y. Ogawa and W. J. Calhoun, "The role of leukotrienes in airway inflammation," Journal of Allergy and Clinical Immunology, vol. 118, no. 4, pp. 789-798, 2006.

[94] W. W. Thompson, D. K. Shay, E. Weintraub et al., "Influenzaassociated hospitalizations in the United States," Journal of the American Medical Association, vol. 292, no. 11, pp. 13331340, 2004.

[95] S. M. Y. Lee, C. Y. Cheung, J. M. Nicholls et al., "Hyperinduction of cyclooxygenase-2-mediated proinflammatory cascade: a mechanism for the pathogenesis of avian influenza H5N1 infection," Journal of Infectious Diseases, vol. 198, no. 4, pp. 525-535, 2008.

[96] P. C. Y. Woo, E. T. K. Tung, K. H. Chan, C. C. Y. Lau, S. K. P. Lau, and K. Y. Yuen, "Cytokine profiles induced by the novel swine-origin influenza A/H1N1 virus: implications for treatment strategies," Journal of Infectious Diseases, vol. 201, no. 3, pp. 346-353, 2010.

[97] I. Darwish, S. Mubareka, and W. C. Liles, "Immunomodulatory therapy for severe influenza," Expert Review of AntiInfective Therapy, vol. 9, no. 7, pp. 807-822, 2011.

[98] M. A. Carey, J. A. Bradbury, Y. D. Rebolloso, J. P. Graves, D. C. Zeldin, and D. R. Germolec, "Pharmacologic inhibition of COX-1 and COX-2 in influenza a viral infection in mice," PLoS One, vol. 5, no. 7, Article ID e11610, 2010.

[99] M. A. Carey, J. A. Bradbury, J. M. Seubert, R. Langenbach, D. C. Zeldin, and D. R. Germolec, "Contrasting effects of cyclooxygenase-1 (COX-1) and COX-2 deficiency on the host response to influenza A viral infection," Journal of Immunology, vol. 175, no. 10, pp. 6878-6884, 2005.

[100] R. J. Hodges, R. G. Jenkins, C. P. D. Wheeler-Jones et al., "Severity of lung injury in cyclooxygenase-2-deficient mice is dependent on reduced prostaglandin E2 production," American Journal of Pathology, vol. 165, no. 5, pp. 1663-1676, 2004.

[101] H. Allgayer, "Review article: mechanisms of action of mesalazine in preventing colorectal carcinoma in inflammatory bowel disease," Alimentary Pharmacology \& Therapeutics, vol. 18, supplement 2, pp. 10-14, 2003.

[102] B. J. Zheng, K. W. Chan, Y. P. Lin et al., "Delayed antiviral plus immunomodulator treatment still reduces mortality in mice infected by high inoculum of influenza A/H5N1 virus," Proceedings of the National Academy of Sciences of the United States of America, vol. 105, no. 23, pp. 8091-8096, 2008.

[103] S. N. Lauder, P. R. Taylor, S. R. Clark et al., "Paracetamol reduces influenza-induced immunopathology in a mouse model of infection without compromising virus clearance or the generation of protective immunity," Thorax, vol. 66, no. 5, pp. 368-374, 2011.

[104] B. Hinz, O. Cheremina, and K. Brune, "Acetaminophen (paracetamol) is a selective cyclooxygenase-2 inhibitor in man," FASEB Journal, vol. 22, no. 2, pp. 383-390, 2008.

[105] B. Rocca and G. A. FitzGerald, "Cyclooxygenases and prostaglandins: shaping up the immune response," International Immunopharmacology, vol. 2, no. 5, pp. 603-630, 2002.

[106] C. Li, A. Bankhead, A. J. Eisfeld et al., "Host regulatory network response to infection with highly pathogenic H5N1 avian influenza virus," Journal of virology, vol. 85, no. 21, pp. 10955-10967, 2011.

[107] D. A. Gentile, P. Fireman, and D. P. Skoner, "Elevations of local leukotriene $\mathrm{C} 4$ levels during viral upper respiratory tract infections," Annals of Allergy, Asthma and Immunology, vol. 91, no. 3, pp. 270-274, 2003.

[108] T. Hennet, H. J. Ziltener, K. Frei, and E. Peterhans, "A kinetic study of immune mediators in the lungs of mice infected with influenza A virus," Journal of Immunology, vol. 149, no. 3, pp. 932-939, 1992.

[109] H. Widegren, M. Andersson, P. Borgeat, L. Flamand, S. Johnston, and L. Greiff, "LTB4 increases nasal neutrophil activity and conditions neutrophils to exert antiviral effects," Respiratory Medicine, vol. 105, no. 7, pp. 997-1006, 2011.

[110] A. J. Duffield-Lillico, J. O. Boyle, K. Z. Xi et al., "Levels of prostaglandin E metabolite and leukotriene E4 are increased in the urine of smokers: evidence that celecoxib shunts arachidonic acid into the 5-lipoxygenase pathway," Cancer Prevention Research, vol. 2, no. 4, pp. 322-329, 2009.

[111] E. J. Schenkelaars and I. L. Bonta, "Cyclooxygenase inhibitors promote the leukotriene $\mathrm{C} 4$ induced release of beta-glucuronidase from rat peritoneal macrophages: prostaglandin E2 suppresses," International Journal of Immunopharmacology, vol. 8, pp. 305-311, 1986.

[112] M. S. Lee, R. E. Walker, and P. M. Mendelman, "Medical burden of respiratory syncytial virus and parainfluenza virus type 3 infection among US children. Implications for design of vaccine trials," Human Vaccines, vol. 1, no. 1, pp. 6-11, 2005.

[113] C. L. Collins and A. J. Pollard, "Respiratory syncytial virus infections in children and adults," Journal of Infection, vol. 45, no. 1, pp. 10-17, 2002.

[114] A. R. Falsey, P. A. Hennessey, M. A. Formica, C. Cox, and E. E. Walsh, "Respiratory syncytial virus infection in elderly and high-risk adults," New England Journal of Medicine, vol. 352, no. 17, pp. 1749-1759, 2005.

[115] A. R. Falsey and E. E. Walsh, "Respiratory syncytial virus infection in adults," Clinical Microbiology Reviews, vol. 13, no. 3, pp. 371-384, 2000.

[116] T. Liu, W. Zaman, B. S. Kaphalia, G. A. S. Ansari, R. P. Garofalo, and A. Casola, "RSV-induced prostaglandin E2 production occurs via cPLA2 activation: role in viral replication,” Virology, vol. 343, no. 1, pp. 12-24, 2005.

[117] J. Y. Richardson, M. G. Ottolini, L. Pletneva et al., "Respiratory syncytial virus (RSV) infection induces cyclooxygenase 2: a potential target for RSV therapy," Journal of Immunology, vol. 174, no. 7, pp. 4356-4364, 2005.

[118] Z. A. Radi, D. K. Meyerholz, and M. R. Ackermann, "Pulmonary cyclooxygenase-1 (COX-1) and COX-2 cellular expression and distribution after respiratory syncytial virus and parainfluenza virus infection," Viral Immunology, vol. 23, no. 1, pp. 43-48, 2010.

[119] Y. Sznajer, J. Y. Westcott, S. E. Wenzel, B. Mazer, M. Tucci, and B. Joseph Toledano, "Airway eicosanoids in acute 
severe respiratory syncytial virus bronchiolitis," Journal of Pediatrics, vol. 145, no. 1, pp. 115-118, 2004.

[120] J. Han, Y. Jia, K. Takeda et al., "Montelukast during primary infection prevents airway hyperresponsiveness and inflammation after reinfection with respiratory syncytial virus," American Journal of Respiratory and Critical Care Medicine, vol. 182, no. 4, pp. 455-463, 2010.

[121] J. J. Fullmer, A. M. Khan, O. Elidemir, C. Chiappetta, J. M. Stark, and G. N. Colasurdo, "Role of cysteinyl leukotrienes in airway inflammation and responsiveness following RSV infection in BALB/c mice," Pediatric Allergy and Immunology, vol. 16, no. 7, pp. 593-601, 2005.

[122] R. C. Welliver, K. H. Hintz, M. Glori, and R. C. Welliver, "Zileuton reduces respiratory illness and lung inflammation, during respiratory syncytial virus infection, in mice," Journal of Infectious Diseases, vol. 187, no. 11, pp. 1773-1779, 2003.

[123] K. K. Chang, Y. K. Ji, H. H. Tae, K. K. Do, I. K. Beyong, and Y. K. Young, "Increased levels tdof BAL cysteinyl leukotrienes in acute RSV bronchiolitis," Acta Paediatrica, International Journal of Paediatrics, vol. 95, no. 4, pp. 479-485, 2006.

[124] G. Piedimonte, G. Renzetti, A. Auais et al., "Leukotriene synthesis during respiratory syncytial virus bronchiolitis: influence of age and atopy," Pediatric Pulmonology, vol. 40, no. 4, pp. 285-291, 2005.

[125] L. D. Dalt, S. Callegaro, S. Carraro, B. Andreola, M. Corradi, and E. Baraldi, "Nasal lavage leukotrienes in infants with RSV bronchiolitis," Pediatric Allergy and Immunology, vol. 18, no. 2, pp. 100-104, 2007.

[126] B. Volovitz, R. C. Welliver, G. De Castro, D. A. Krystofik, and P. L. Ogra, "The release of leukotrienes in the respiratory tract during infection with respiratory syncytial virus: role in obstructive airway disease," Pediatric Research, vol. 24, no. 4, pp. 504-507, 1988.

[127] S. M. Van Schaik, D. A. Tristram, I. S. Nagpal, K. M. Hintz, R. C. Welliver, and R. C. Welliver, "Increased production of IFN$\gamma$ and cysteinyl leukotrienes in virus- induced wheezing," Journal of Allergy and Clinical Immunology, vol. 103, no. 4, pp. 630-636, 1999.

[128] G. A. Prince, A. Mathews, S. J. Curtis, and D. D. Porter, "Treatment of respiratory syncytial virus bronchiolitis and pneumonia in a cotton rat model with systemically administered monoclonal antibody (palivizumab) and glucocorticosteroid," Journal of Infectious Diseases, vol. 182, no. 5, pp. 1326-1330, 2000.

[129] C. A. Bonville, H. F. Rosenberg, and J. B. Domachowske, "Ribavirin and cysteinyl leukotriene-1 receptor blockade as treatment for severe bronchiolitis," Antiviral Research, vol. 69, no. 2, pp. 53-59, 2006.

[130] K. Wedde-Beer, C. Hu, M. M. Rodriguez, and G. Piedimonte, "Leukotrienes mediate neurogenic inflammation in lungs of young rats infected with respiratory syncytial virus," American Journal of Physiology, vol. 282, no. 5, pp. L1143L1150, 2002.

[131] H. Bisgaard, "A randomized trial of montelukast in respiratory syncytial virus postbronchiolitis," American Journal of Respiratory and Critical Care Medicine, vol. 167, no. 3, pp. 379-383, 2003.

[132] H. Bisgaard, A. Flores-Nunez, A. Goh et al., "Study of montelukast for the treatment of respiratory symptoms of post-respiratory syncytial virus bronchiolitis in children," American Journal of Respiratory and Critical Care Medicine, vol. 178, no. 8, pp. 854-860, 2008.
[133] M. Proesmans, K. Sauer, E. Govaere, M. Raes, G. De Bilderling, and K. De Boeck, "Montelukast does not prevent reactive airway disease in young children hospitalized for RSV bronchiolitis," Acta Paediatrica, International Journal of Paediatrics, vol. 98, no. 11, pp. 1830-1834, 2009.

[134] M. Wright and G. Piedimonte, "Respiratory syncytial virus prevention and therapy: past, present, and future," Pediatric Pulmonology, vol. 46, no. 4, pp. 324-347, 2011.

[135] M. L. Seymour, N. Gilby, P. G. Bardin et al., "Rhinovirus infection increases 5-lipoxygenase and cyclooxygenase-2 in bronchial biopsy specimens from nonatopic subjects," Journal of Infectious Diseases, vol. 185, no. 4, pp. 540-544, 2002.

[136] C. A. Culver and S. M. Laster, "Adenovirus type 5 exerts multiple effects on the expression and activity of cytosolic phospholipase A2, cyclooxygenase-2, and prostaglandin synthesis," Journal of Immunology, vol. 179, no. 6, pp. 4170-4179, 2007.

[137] L. J. Crofford, K. T. McDonagh, S. Guo et al., "Adenovirus binding to cultured synoviocytes triggers signaling through MAPK pathways and induces expression of cyclooxygenase2," Journal of Gene Medicine, vol. 7, no. 3, pp. 288-296, 2005.

[138] J. B. Weinberg, G. S. Stempfle, J. E. Wilkinson, J. G. Younger, and K. R. Spindler, "Acute respiratory infection with mouse adenovirus type 1," Virology, vol. 340, no. 2, pp. 245-254, 2005.

[139] D. Knipe, P. Howley, D. Griffin et al., Fields Virology, Lippincott Williams \& Wilkins, Philadelphia, Pa, USA, 5th edition, 2007.

[140] H. Qiu, K. Strååt, A. Rahbar, M. Wan, C. Söderberg-Nauclér, and J. Z. Haeggström, "Human CMV infection induces 5-lipoxygenase expression and leukotriene B4 production in vascular smooth muscle cells," Journal of Experimental Medicine, vol. 205, no. 1, pp. 19-24, 2008.

[141] H. Zhu, J. P. Cong, D. Yu, W. A. Bresnahan, and T. E. Shenk, "Inhibition of cyclooxygenase 2 blocks human cytomegalovirus replication," Proceedings of the National Academy of Sciences of the United States of America, vol. 99, no. 6, pp. 3932-3937, 2002.

[142] J. Schröer and T. Shenk, "Inhibition of cyclooxygenase activity blocks cell-to-cell spread of human cytomegalovirus," Proceedings of the National Academy of Sciences of the United States of America, vol. 105, no. 49, pp. 19468-19473, 2008.

[143] J. Gosselin, P. Borgeat, and L. Flamand, "Leukotriene B4 protects latently infected mice against murine cytomegalovirus reactivation following allogeneic transplantation," Journal of Immunology, vol. 174, no. 3, pp. 1587-1593, 2005.

[144] M. N. Ballinger, D. M. Aronoff, T. R. McMillan et al., "Critical role of prostaglandin E2 overproduction in impaired pulmonary host response following bone marrow transplantation," Journal of Immunology, vol. 177, no. 8, pp. 5499-5508, 2006.

[145] C. I. Ojielo, K. Cooke, P. Mancuso et al., "Defective phagocytosis and clearance of Pseudomonas aeruginosa in the lung following bone marrow transplantation," Journal of Immunology, vol. 171, no. 8, pp. 4416-4424, 2003.

[146] C. Chaimoff, T. Malachi, and I. Halbrecht, "Prostaglandin E2 and cyclic nucleotides in plasma and urine of colonic cancer patients," Journal of Cancer Research and Clinical Oncology, vol. 110, no. 2, pp. 153-156, 1985.

[147] V. Fraifeld, J. Kaplanski, T. Kukulansky, and A. Globerson, "Increased prostaglandin E2 production by concanavalin Astimulated splenocytes of old mice," Gerontology, vol. 41, no. 3, pp. 129-133, 1995. 
[148] I. Ramis, J. Rosello-Catafau, G. Gomez, J. M. Zabay, E. Fernandez Cruz, and E. Gelpi, "Cyclooxygenase and lipoxygenase arachidonic acid metabolism by monocytes from human immune deficiency virus-infected drug users," Journal of Chromatography, vol. 557, pp. 507-513, 1991.

[149] G. M. Anstead, Q. Zhang, and P. C. Melby, "Malnutrition promotes prostaglandin over leukotriene production and dysregulates eicosanoid-cytokine crosstalk in activated resident macrophages," Prostaglandins, Leukotrienes and Essential Fatty Acids, vol. 81, no. 1, pp. 41-51, 2009.

[150] H. P. Redmond, J. Shou, C. J. Kelly et al., "Immunosuppressive mechanisms in protein-calorie malnutrition," Surgery, vol. 110, no. 2, pp. 311-317, 1991.

[151] S. J. Cayeux, P. C. L. Beverley, R. Schulz, and B. Dorken, "Elevated plasma prostaglandin E2 levels found in 14 patients undergoing autologous bone marrow or stem cell transplantation," Bone Marrow Transplantation, vol. 12, no. 6, pp. 603-608, 1993.

[152] M. M. H. El-Sharabasy and M. M. El-Naggar, "Prostaglandin E2 in renal transplant recipients," International Urology and Nephrology, vol. 24, no. 4, pp. 447-451, 1992.

[153] N. M. H. Graham, C. J. Burrell, R. M. Douglas, P. Debelle, and L. Davies, "Adverse effects of aspirin, acetaminophen, and ibuprofen on immune function, viral shedding, and clinical status in rhinovirus-infected volunteers," Journal of Infectious Diseases, vol. 162, no. 6, pp. 1277-1282, 1990.

[154] R. Prymula, C. A. Siegrist, R. Chlibek et al., "Effect of prophylactic paracetamol administration at time of vaccination on febrile reactions and antibody responses in children: two open-label, randomised controlled trials," The Lancet, vol. 374, no. 9698, pp. 1339-1350, 2009. 


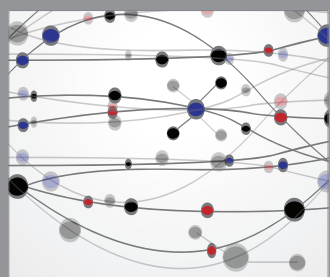

The Scientific World Journal
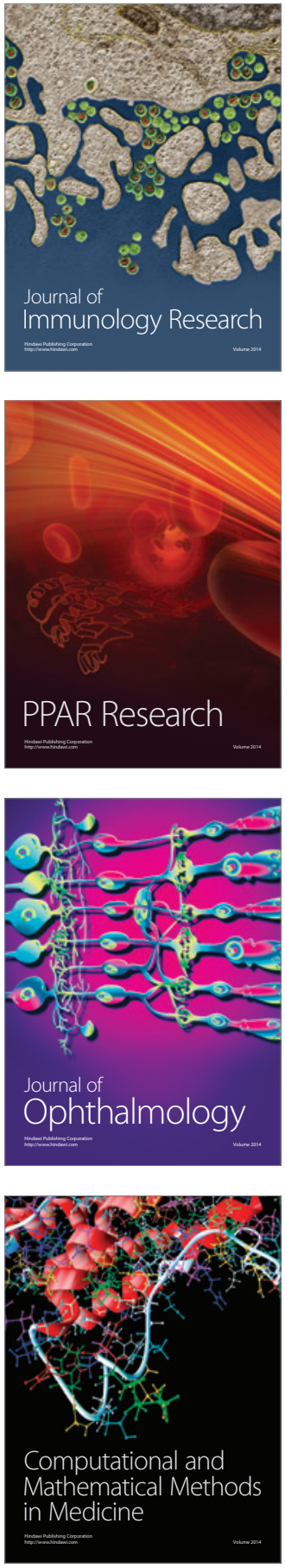

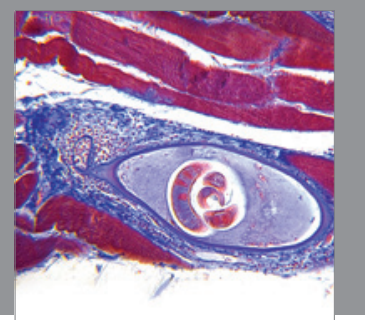

Gastroenterology

Research and Practice
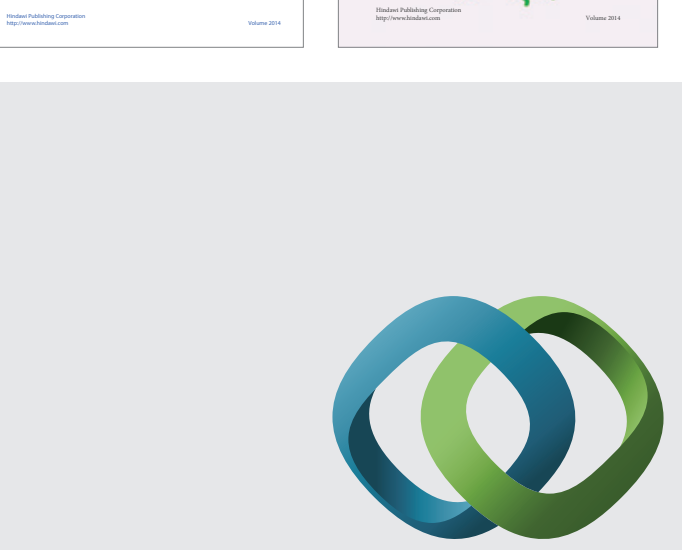

\section{Hindawi}

Submit your manuscripts at

http://www.hindawi.com
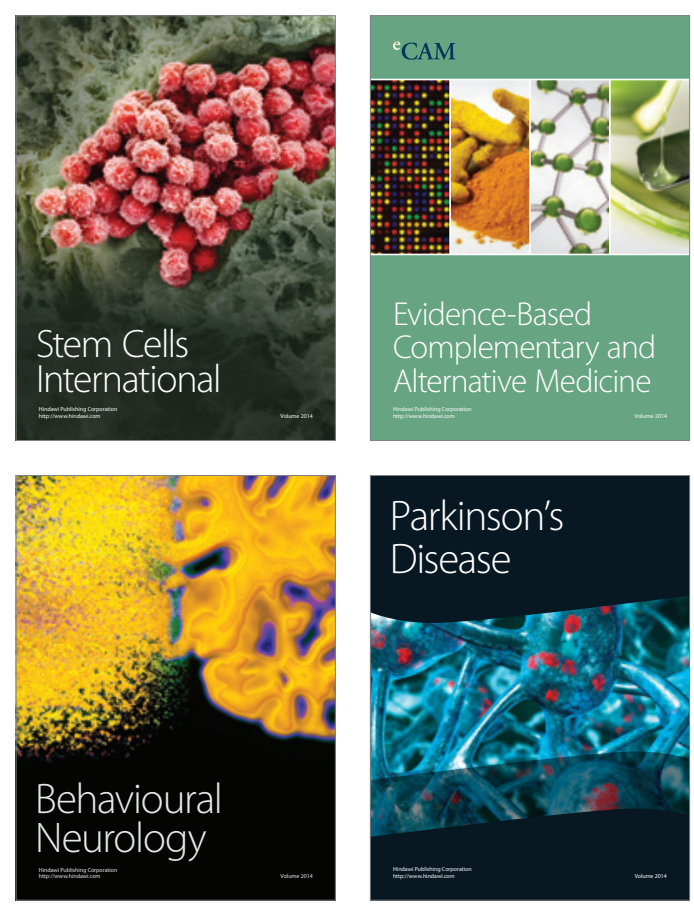

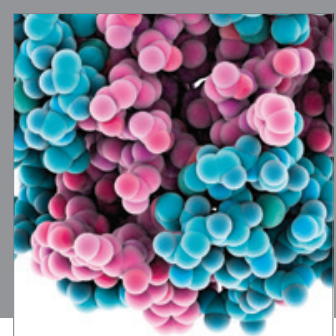

Journal of
Diabetes Research

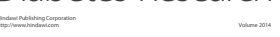

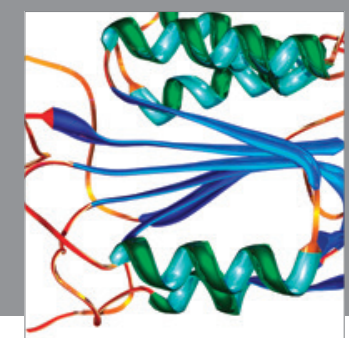

Disease Markers
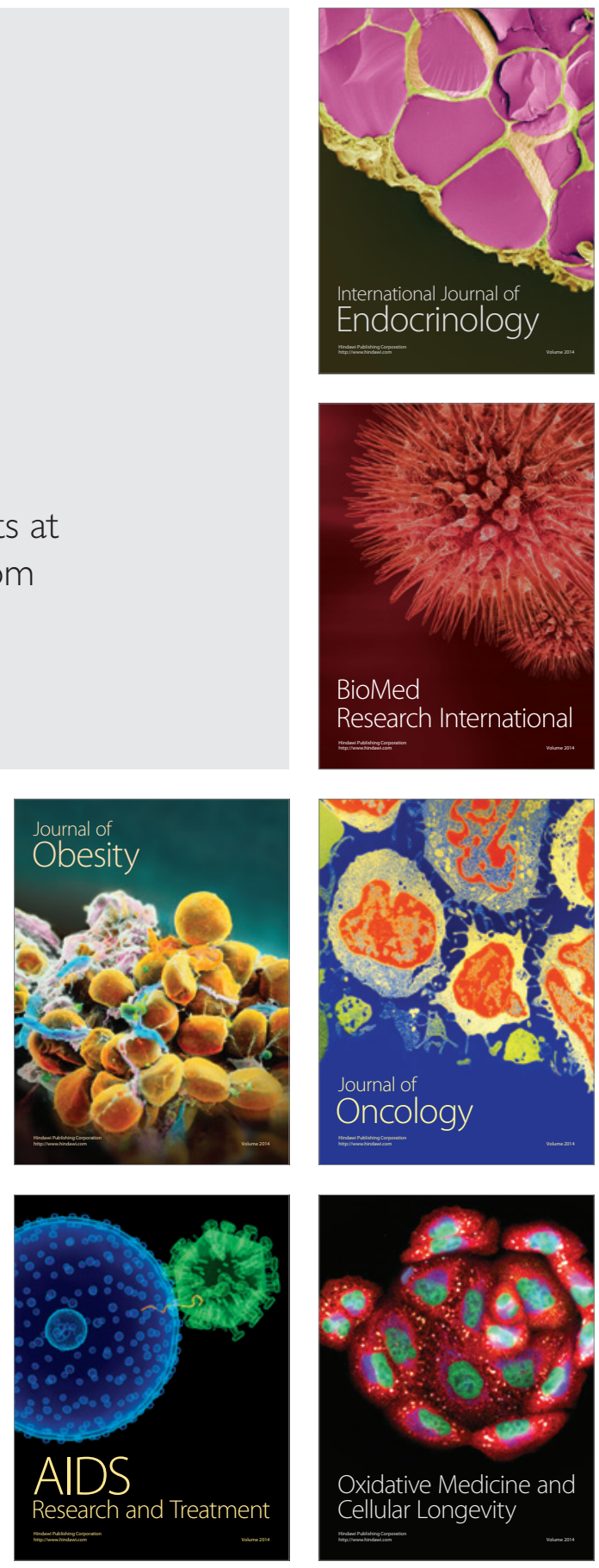